\begin{tabular}{|c|c|c|}
\hline & Int.J.Curr.Microbiol.App.Sci (2021) 10(12): 158-168 & \\
\hline & $\begin{array}{l}\text { International Journal of Current Microbiology and Applied Sciences } \\
\text { ISSN: 2319-7706 Volume } \mathbf{1 0} \text { Number } \mathbf{1 2} \mathbf{( 2 0 2 1 )} \\
\text { Journal homepage: } \underline{\text { http://www.ijcmas.com }}\end{array}$ & 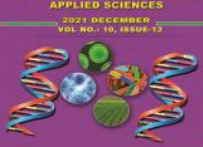 \\
\hline $\begin{array}{l}\text { EXCELLENT } \\
\text { PUBLISHERS }\end{array}$ & & \\
\hline
\end{tabular}

\title{
Comparative Study of Performance Evaluation of Biomass based Rotary Tray Dryer and Solar Tunnel Dryer for Drying of Shatavari Roots (Asparagus racemosus)
}

\author{
B. V. Ghanbahadur, N. R. Nandagawali and V. B. Shinde*
}

Department of Unconventional Energy Sources and Electrical Engineering, College of Agricultural Engineering and Technology, Dr. Panjabrao Deshmukh Krishi Vidyapeeth, Akola P.O. Krishi Nagar- 444 104, M.S., India

*Corresponding author

\section{A B S T R A C T}

Keywords

Asparagus

racemosus,

Shatavari, Drying

Article Info

Received:

09 November 2021

Accepted:

05 December 2021

Available Online:

10 December 2021
The project entitled "Comparative study of performance evaluation of biomass based rotary tray dryer and solar tunnel dryer for drying of Shatavari" is carried out at Department of Unconventional Energy Source and Electrical Engineering, Dr. PDKV, Akola undertaken with the objectives to characterize agro residues based briquettes used for combustion in biomass based rotary tray dryer and evaluate performance of biomass based rotary tray dryer for drying of Shatavari in biomass based rotary tray dryer and solar tunnel dryer. The biomass heated air was supply to continuously to the drying chamber for drying of Shatavari roots. To the drying of Shatavari temperature ranges was used $45^{\circ}, 55^{\circ}$ and $65^{\circ} \mathrm{C}$. The drying of Shatavri to the temperature in biomass heated air rotary tray dryer and solar tunnel drying result observed the inside drying chamber and combustor temperature were much higher than the ambient temperature during drying time. The drying process observed that drying time was minimized and organic content obtained more in biomass heated air rotary tray dryer was found better than solar tunnel drying. The quantitative analysis showed that the traditional drying i.e.., solar tunnel drying took $17 \mathrm{~h}$ for drying of Shatavari roots to remove moisture content from $42.83 \%$ (db) to $9.37 \%$ (db), while biomass heated air rotary tray dryer took only $14 \mathrm{~h}$ for drying of Shatavari roots during $45^{\circ}, 55^{\circ}$ and $65^{\circ} \mathrm{C}$ required $12 \mathrm{~h}$ moisture content was removed $8.33 \%(\mathrm{db})$ respectively.

\section{Introduction}

Asparagus racemosus (family Asparagaceae; Liliaceous), is commonly called Shatavari, Satawar or Satmuli in Hindi. The plant grows throughout the tropical and subtropical parts of India up to an altitude of $1500 \mathrm{~m}$. The plant is a spinous under-shrub, with tuberous, short rootstock bearing numerous succulent tuberous roots $(30-100 \mathrm{~cm}$ long and $1-2 \mathrm{~cm}$ thick) that are silvery white or ash colored externally and white internally. These roots 
are the part that finds use in various medicinal preparations. The root Asparagus racemosus (Shatavari) also has proved its effectiveness as a natural sex stimulant and spermaticgenie medicine in both male and female sexual and gynecological disorders. The root is important for increasing the seminal qualities due to its ability to increase sperm count as well as improves its motility enhances libido due to its general tonic effects. It also acts as a nutritive tonic.

Biomass is an organic matter of biological origin as a form of stored solar energy which, is captured by the organic matter as it grows.

Biomass is a renewable energy source and agriculture is its largest producer. For the agriculture sector, biomass will assume an increasingly important role as an energy source. Biomass is an important source of energy accounting for about one third of the total fuel used in India and in about $90 \%$ of the rural households.

Drying is a universal method of conditioning the grain to safe moisture content level. There are different sources of energy which can be integrated for drying purposes. However; solar drying offers a promising option in present energy quest for drying agricultural and industrial products.

The selection of the best type of dryer is not challenging task but that should not be taken lightly nor should it be let entirely to dryer vendors who typically specialize in only few types of dryer. The user must take a proactive role and employ vendors experience and bench scale or pilot scale facilities to obtain data, which can be assessed for a comparative evaluation of several options A wrong dryer for given application is still a poor dryer, regardless of how well it is designed. Open sun drying is slow and exposes the produce to various losses and deterioration in quality.
The main objectives includes to evaluate performance of biomass based rotary tray dryer. And also to evaluate performance of Solar tunnel dryer.

\section{Materials and Methods}

\section{Biomass based rotary tray dryer}

The biomass heated air rotary tray dryer tested in full load condition Shatavari roots dried at different temperature the selected temperature was below the $45^{\circ} \mathrm{C}$ one trial were taken at selected temperature 45,55 and $65^{\circ} \mathrm{C}$.

In full load test average drying chamber temperature, combustor temperature and relative humidity was obtained in trial $\left(45^{\circ} \mathrm{C}\right)$. $\mathrm{T} 1 \quad\left(54.86^{\circ} \mathrm{C}\right), \mathrm{T} 2(54), \mathrm{T}^{\circ}\left(58.15^{\circ} \mathrm{C}\right), \mathrm{T} 4$ $\left(51.92^{\circ} \mathrm{C}\right), \mathrm{T}^{\circ}\left(57.23^{\circ} \mathrm{C}\right), \mathrm{T}^{\circ}\left(50.38^{\circ} \mathrm{C}\right), \mathrm{T} 7$ $\left(54.38^{\circ} \mathrm{C}\right), \quad \mathrm{T} 8 \quad\left(51.46^{\circ} \mathrm{C}\right)$ and outlet temperature $\left(41.23^{\circ} \mathrm{C}\right)$ respectively. The average relative humidity of dryer was obtained during drying chamber RH1 (23.69\%), RH2 (23.92\%), RH3 (23.84\%), RH4 (22.69\%) and RH5 (24.07\%) respectively.

The average drying chamber efficiency of the biomass heated rotary tray dryer was obtained in this temperature 45,55 and $65^{\circ} \mathrm{C}$.

The fuel rate was not fixed it feed by requirement of temperature and it feeding time also vary required fuel in trial 45,55 and $65^{\circ} \mathrm{C}$ was $0.848 \mathrm{~kg} / \mathrm{hr}, 1.329 \mathrm{~kg} / \mathrm{hr}$ and $1.793 \mathrm{~kg} / \mathrm{hr}$.

\section{Solar tunnel dryer}

In this dryer the material used $65 \mathrm{~kg}$ of shatavari for drying $8 \mathrm{~kg}$ in each tray the total trays are 8 .

It is the most commonly used method for drying in which air is circulated by force convection. The product is spread over the screened trays. The drying medium is air 
which is heated generally in temperature range from ambient to $50^{\circ} \mathrm{C}$ during roots drying. The air velocity ranges from 0.1 to $1.9 \mathrm{~m} / \mathrm{s}$. combined and simultaneous heat and mass transfer operation for which energy must be supplied. The removal of moisture prevents the growth and reproduction of microorganisms like bacteria, yeasts and moulds causing decay and minimizes many of the moisture-mediated deteriorative reactions.

Drying takes place due to the difference in moisture concentration between the drying air and the air in the vicinity of crop surface. The performance of the Solar Tunnel Dryers will evaluated for drying of Shatavari.

\section{Open sun drying}

The sun drying of Shatavari roots was done during the month Feb-March at $35-42^{\circ} \mathrm{C}$ temperature and $30 \%$ relative humidity. Solar drying is a continuous process where moisture content air and product temperature change simultaneously along with the two basic inputs of the system Le the solar insulations and the ambient temperature. The drying rate is affected by ambient climate conditions.

\section{Results and Discussion}

\section{Determination of moisture content}

The initial moisture content of sample was determined by the hot air oven drying method. The samples were placed in hot air oven at $105 \pm 0.5^{0} \mathrm{C}$ for $24.00 \mathrm{~h}$. following formulae were used (Chakraverty, 1988).

$$
\begin{aligned}
& \text { M.C. }(\mathrm{wb}) \%=\frac{\left(\mathrm{W}_{1}-\mathrm{W}_{2}\right)}{\mathrm{W}_{1}} \times 100 \\
& \text { M.C.(db) } \%=\frac{\left(\mathrm{W}_{1}-\mathrm{W}_{2}\right)}{\mathrm{W}_{2}} \times 100
\end{aligned}
$$

Where,

$\mathrm{W}_{1}=$ Weight of sample before drying, $\mathrm{g}$

$\mathrm{W}_{2}=$ Weight of bone dried sample, $\mathrm{g}$

\section{Determination of moisture ratio}

The Moisture ratio of the produce will be computed by following formula (Chakraverty, 1988).

Moisture Ratio (M.R.) $=\frac{\left(\mathrm{M}-\mathrm{M}_{\mathrm{e}}\right)}{\left(\mathrm{M}_{0}-\mathrm{M}_{\mathrm{e}}\right)}$

Where,

$\mathrm{M}=$ Moisture content (db) in \%

$\mathrm{M}_{\mathrm{e}}=\mathrm{EMC},(\mathrm{db})$ in $\%$

$\mathrm{M}_{0}=\mathrm{IMC},(\mathrm{db})$ in $\%$

\section{Determination of drying rate}

The drying rate of produce sample during drying period will be determined as follows: (Chakraverty, 1988).

Drying rate $\left(D_{R}\right)=\frac{\Delta W}{\Delta t}$

Where,

$\Delta \mathrm{W}=$ Weight loss in one $\mathrm{h}$ interval (gm/100gm b/dm min.)

$\Delta \mathrm{T}=$ Difference in time reading $(\mathrm{h})$

In full load test the Shatavari roots was poured in the perforated iron tray in thin layer. The experiment was conducted on threshed Shatavari roots. The initial weight of the samples was recorded. The samples were 
weighed regularly at an interval of $2.00 \mathrm{~h}$ and simultaneously the temperature, relative humidity was noted. The drying was conducted between 9.00 to $17.00 \mathrm{~h}$ daily up till it reaches to equilibrium moisture.

\section{Full load testing of Solar Tunnel Dryer}

In full load test the roots of Shatavari will spread over the perforated aluminum tray in thin layer. The experiment will be conducted after harvesting of Shatavari. The initial weight of the samples will be recorded.

The samples will be weighed regularly at an interval of $2.00 \mathrm{~h}$ and simultaneously the temperature, relative humidity, solar radiation and wind velocity will be recorded. The drying will be conducted between 9.00 to $17.00 \mathrm{~h}$ daily.

\section{Variations in temperature during the drying of Shatavari in solar tunnel dryer}

The data presented showed that the initial moisture content and representing reduction in moisture content after $2 \mathrm{hrs}$ interval in solar tunnel dryer and fig 4.18 showed that the ambient temperature and solar radiations with respect to drying time. It showed that initial temperature just after starting of drier was $29.3^{\circ} \mathrm{C}$ corresponding to the ambient temperature $33.3^{\circ} \mathrm{C}$. The minimum and maximum temperatures inside the solar tunnel dryer were $39.2^{\circ} \mathrm{C}$ and $60.2^{\circ} \mathrm{C}$ respectively corresponding temperature of $60^{\circ} \mathrm{C}$ respectively. The outlet temperature was $33.8^{\circ} \mathrm{C}$.

\section{Variation in weight loss of Shatavari roots in biomass based rotary tray dryer}

The data showed that the moisture content of Shatavari roots decrease of $2 \mathrm{hrs}$ interval in the biomass based rotary tray dryer, ambient temperature and relative humidity with respect to drying time. It showed that initial moisture content of each tray just after starting of drier was $20^{\circ} \mathrm{C}$ corresponding to the ambient temperature $23^{\circ} \mathrm{C}$. The minimum and maximum temperatures inside the biomass based rotary tray dryer were $54^{\circ} \mathrm{C}$ and $69^{\circ} \mathrm{C}$ respectively corresponding to the constant feeding temperature of $65^{\circ} \mathrm{C}$ at $2800 \mathrm{rpm}$.

The data presented in Fig. 1 showed that the ambient temperature and relative humidity during full load test. It showed that minimum ambient temperature was $25^{\circ} \mathrm{C}$ at 9:30 $\mathrm{h}$. Maximum ambient temperature attained was $44^{\circ} \mathrm{C}$ at $14: 30 \mathrm{~h}$ with corresponding ambient relative humidity of $13 \%$ respectively

The data presented in Fig 2 showed that the relative humidity with respect to drying time. It showed that initial temperature just after starting of drier was $27^{\circ} \mathrm{C}$ corresponding to the ambient temperature $33^{\circ} \mathrm{C}$. The minimum and maximum temperatures inside the biomass based rotary tray dryer were $45^{\circ} \mathrm{C}$ and $55^{\circ} \mathrm{C}$ respectively corresponding to the constant feeding temperature of $45^{\circ} \mathrm{C}$ at $2800 \mathrm{rpm}$ respectively. The outlet temperature was $36^{\circ} \mathrm{C}$. The relative humidity inside the biomass rotary drier was found to be $22 \%$ corresponding to ambient relative humidity $29 \%$ respectively. 
Table.1 Variations in temperature during the drying of Shatavari in solar tunnel dryer

\begin{tabular}{|l|c|c|c|c|c|c|c|c|c|}
\hline $\begin{array}{l}\text { Sr. } \\
\text { No }\end{array}$ & $\begin{array}{c}\text { Time. } \\
\text { (hr) }\end{array}$ & $\begin{array}{c}\text { Temp. } \\
\text { Front } \\
\text { side in } \\
\text { the dryer }\end{array}$ & $\begin{array}{c}\text { Temp. at } \\
\text { middle in the } \\
\text { dryer }\end{array}$ & $\begin{array}{c}\text { Temp. at } \\
\text { end side } \\
\text { in the } \\
\text { dryer }\end{array}$ & $\begin{array}{c}\text { Tem. } \\
\text { Upper } \\
\text { tray }\end{array}$ & $\begin{array}{c}\text { Temp. } \\
\text { middle } \\
\text { tray }\end{array}$ & $\begin{array}{c}\text { Temp } \\
\text { lower } \\
\text { tray }\end{array}$ & $\begin{array}{c}\text { Amb.Temp. } \\
\left({ }^{\circ} \mathbf{C}\right)\end{array}$ & $\begin{array}{c}\text { Solar } \\
\text { radiation } \\
\left(\mathbf{W} / \mathbf{m}^{2}\right)\end{array}$ \\
\hline $\mathbf{1 .}$ & $09: 00$ & 35.9 & 39.6 & 39.2 & 43.0 & 39.6 & 41.2 & 29.3 & $\mathbf{2 0 0}$ \\
\hline $\mathbf{2 .}$ & $11: 00$ & 51.7 & 46.2 & 55.5 & 61.0 & 54.0 & 52.6 & 35.7 & $\mathbf{5 7 0}$ \\
\hline $\mathbf{3 .}$ & $14: 00$ & 54.9 & 60.2 & 57.8 & 65.2 & 57.8 & 56.1 & 37.4 & $\mathbf{4 2 0}$ \\
\hline $\mathbf{4 .}$ & $15: 00$ & 47.2 & 50.6 & 49.6 & 51.3 & 51.3 & 51.4 & 35.9 & $\mathbf{3 8 0}$ \\
\hline $\mathbf{5 .}$ & $\mathbf{1 7 : 0 0}$ & $\mathbf{4 0 . 1}$ & $\mathbf{4 3 . 1}$ & $\mathbf{4 2 . 8}$ & $\mathbf{4 1 . 9}$ & $\mathbf{4 2 . 0}$ & $\mathbf{4 3 . 7}$ & $\mathbf{3 3 . 3}$ & $\mathbf{2 5 0}$ \\
\hline
\end{tabular}

Table.2 Variation in weight loss of Shatavari roots in biomass based rotary tray dryer

\begin{tabular}{|c|c|c|c|c|c|c|c|}
\hline $\begin{array}{c}\text { No. of Trays. } \\
\text { Day-1 }\end{array}$ & $\begin{array}{l}\text { Wt. of tray } \\
\text { without sample } \\
\text { in }(\mathrm{Kg})\end{array}$ & $\begin{array}{l}\text { Wt. of } \\
\text { sample } \\
\text { in }(\mathrm{Kg})\end{array}$ & $\begin{array}{c}\text { Total wt } \\
\text { of sample } \\
\text { in } \\
\operatorname{tray}(\mathrm{Kg})\end{array}$ & $\begin{array}{l}\text { After } \\
1 \mathrm{hr} .\end{array}$ & $\begin{array}{l}\text { After } \\
2 \mathrm{hr} \text {. }\end{array}$ & $\begin{array}{l}\text { After } \\
\text { 3hr. }\end{array}$ & $\begin{array}{c}\text { After } \\
\text { 4hr. }\end{array}$ \\
\hline 1. & 6.251 & 8.098 & 14.349 & 14.170 & 14.053 & 13.896 & 13.776 \\
\hline 2. & 6.243 & 8.804 & 15.047 & 14.823 & 14.690 & 14.514 & 14.399 \\
\hline 3. & 5.487 & 8.302 & 13.789 & 13.569 & 13.437 & 13.255 & 13.130 \\
\hline 4. & 6.537 & 8.580 & 15.117 & 14.879 & 14.798 & 14.567 & 14.437 \\
\hline 5. & 5.375 & 7.895 & 13.270 & 13.014 & 12.876 & 12.685 & 12.572 \\
\hline 6. & 6.213 & 7.499 & 13.712 & 13.576 & 13.492 & 13.370 & 13.256 \\
\hline 7. & 6.213 & 7.948 & 14.161 & 14.046 & 13.970 & 13.848 & 13.708 \\
\hline 8. & 6.369 & 7.965 & 14.334 & 14.199 & 14.112 & 13.978 & 13.818 \\
\hline
\end{tabular}

Table.3

\begin{tabular}{|c|c|c|c|c|c|c|c|c|c|}
\hline $\begin{array}{l}\text { Temp. at } \\
\text { Position }\end{array}$ & Initial & $\begin{array}{c}\text { After } 1 \\
\text { h }\end{array}$ & $\begin{array}{c}\text { After } 2 \\
\text { h }\end{array}$ & $\begin{array}{c}\text { After } 3 \\
\text { h }\end{array}$ & $\begin{array}{c}\text { After } 4 \\
\text { h }\end{array}$ & $\begin{array}{c}\text { After } 5 \\
\text { h }\end{array}$ & $\begin{array}{c}\text { After } 6 \\
\text { h }\end{array}$ & $\begin{array}{c}\text { After } 7 \\
\text { h }\end{array}$ & $\begin{array}{c}\text { After } 8 \\
\text { h }\end{array}$ \\
\hline Bin T1 & 22 & 48 & 48 & 47 & 47 & 47 & 47 & 46 & 48 \\
\hline Bin $\mathbf{T} 2$ & 21 & 49 & 49 & 48 & 48 & 48 & 48 & 47 & 55 \\
\hline Bin T3 & 25 & 55 & 55 & 54 & 54 & 44 & 44 & 55 & 47 \\
\hline Bin T4 & 18 & 48 & 48 & 47 & 47 & 47 & 47 & 46 & 53 \\
\hline Bin T5 & 24 & 54 & 54 & 52 & 52 & 53 & 53 & 54 & 42 \\
\hline Bin T6 & 19 & 45 & 43 & 42 & 41 & 41 & 41 & 43 & 50 \\
\hline Bin T7 & 21 & 50 & 50 & 49 & 49 & 50 & 50 & 51 & 46 \\
\hline Bin T8 & 17 & 47 & 47 & 46 & 46 & 47 & 47 & 57 & 47 \\
\hline $\begin{array}{c}\text { Bin } \\
\text { Outlet } \\
\text { T9 }\end{array}$ & 26.2 & 36.4 & 36 & 35.8 & 43.9 & 33.9 & 33.9 & 37.2 & 35.5 \\
\hline CHT 1 & 35 & 37 & 37 & 38 & 36 & 36 & 36 & 37 & 37 \\
\hline CHT 2 & 29 & 42 & 41 & 42 & 39 & 39 & 39 & 45 & 39 \\
\hline CHT 3 & 37 & 45 & 45 & 44 & 42 & 41 & 41 & 43 & 43 \\
\hline CHT 4 & 29 & 48 & 46 & 46 & 43 & 42 & 42 & 54 & 45 \\
\hline CHT 6 & 28 & 49 & 50 & 47 & 44 & 45 & 45 & 54 & 47 \\
\hline CHT 7 & 31 & 52 & 36 & 51 & 48 & 49 & 49 & 58 & 38 \\
\hline
\end{tabular}


Fig.1

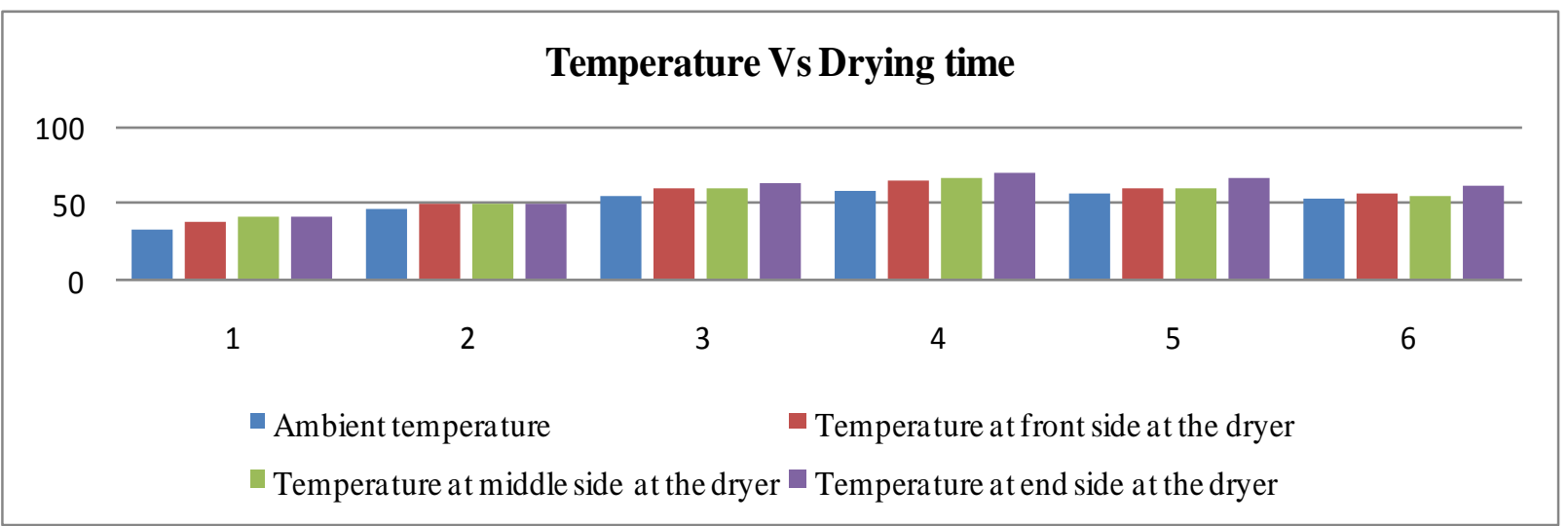

Fig.2 Variation in temperature and relative humidity during full load test in open sun drying of Shatavari roots.

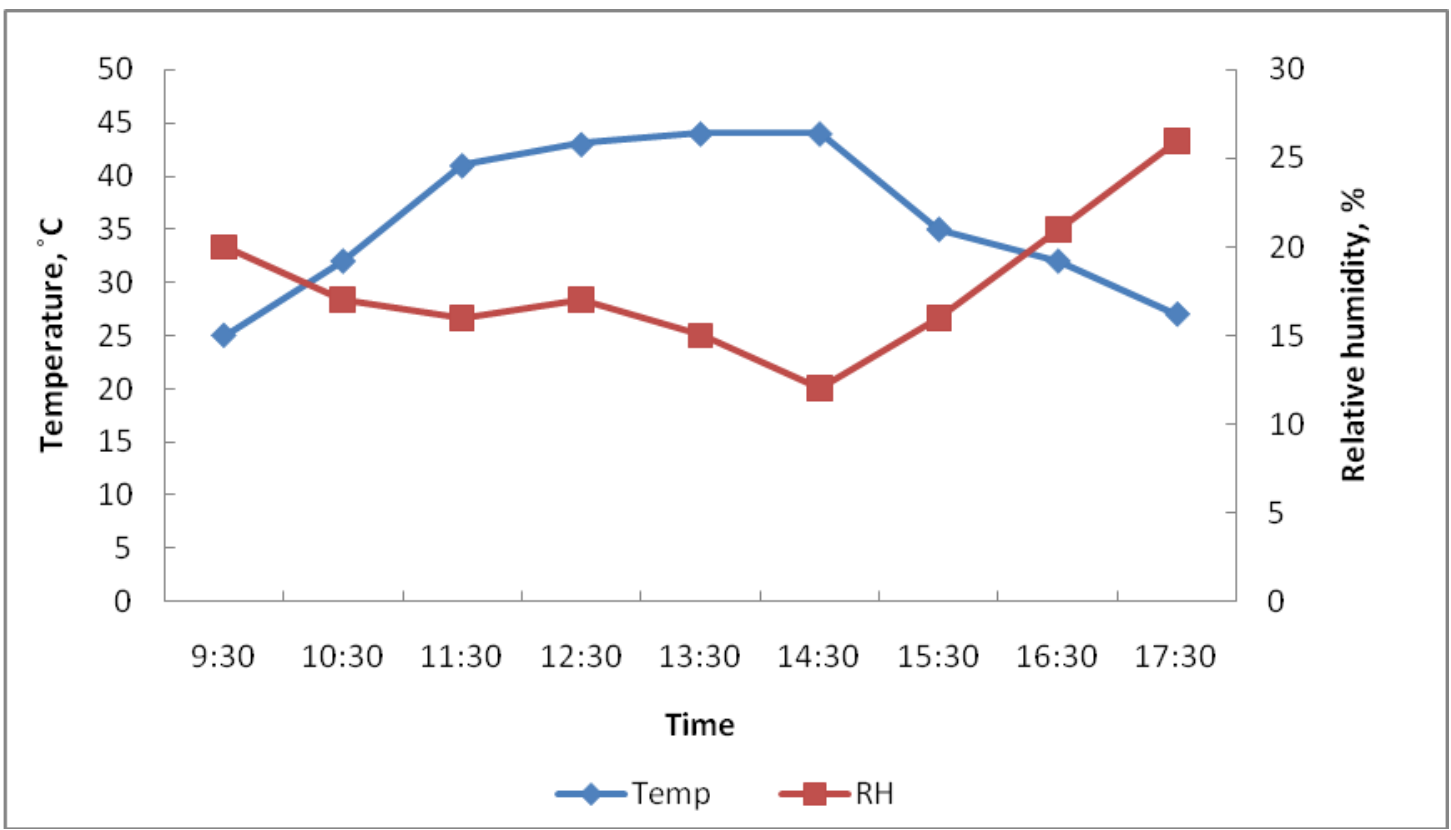


Fig.3 Variation in relative humidity during full load test in biomass based rotary tray dryer with respect to drying time (At $45^{\circ} \mathrm{C} \& 2800 \mathrm{rpm}$ )

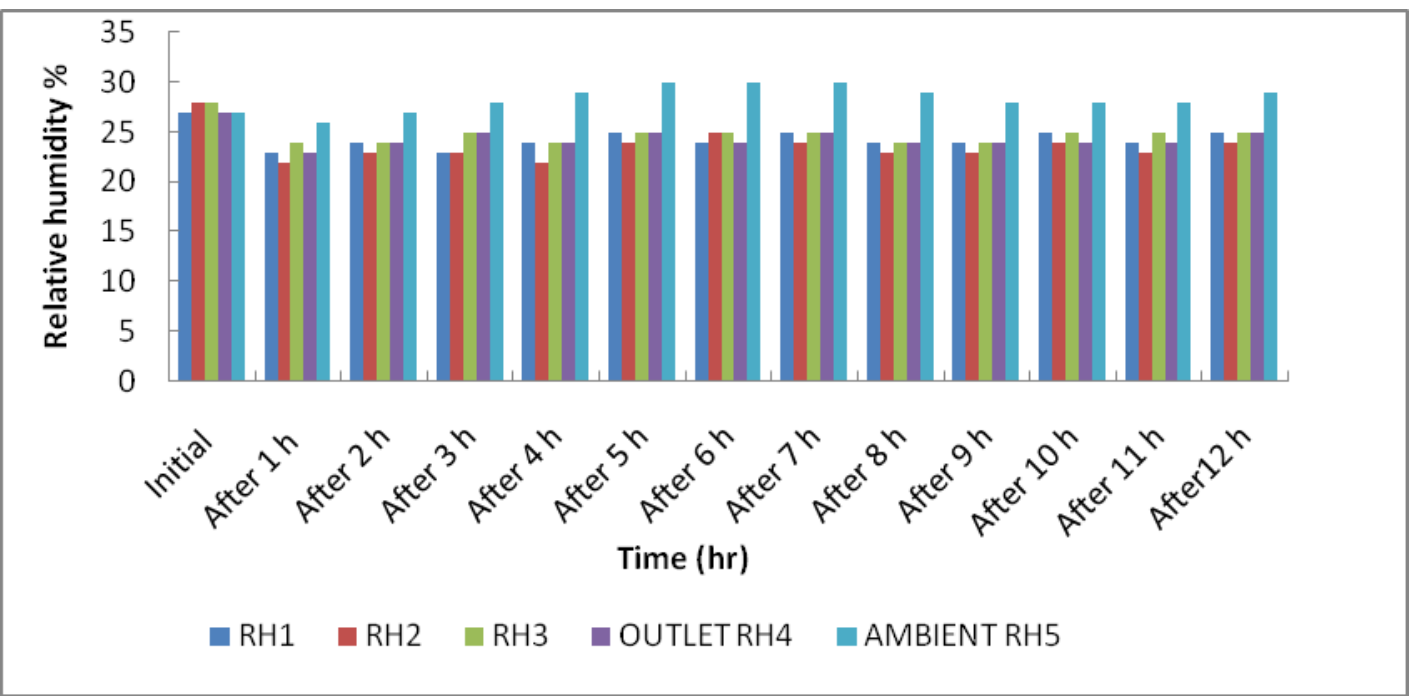

Fig.4 Variation in temperature during full load test in biomass based rotary tray dryer with respect to drying time (At $55^{\circ} \mathrm{C} \& 2800 \mathrm{rpm}$ )

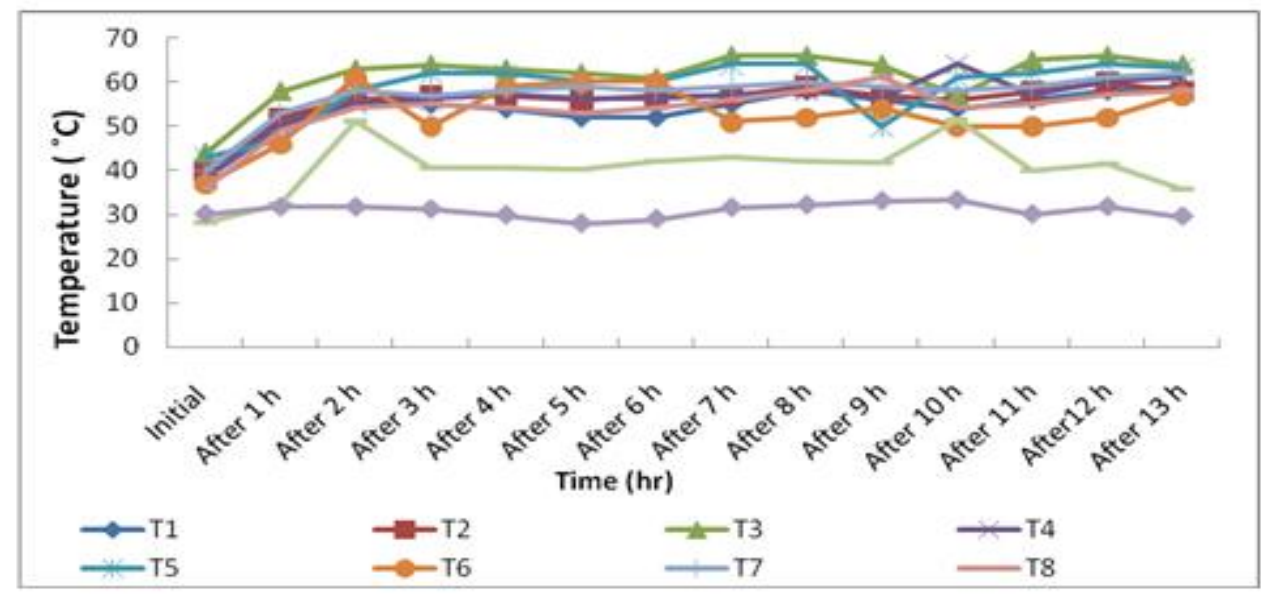


Fig.5 Variation in relative humidity during full load test in biomass based rotary tray dryer with respect to drying time (At $55^{\circ} \mathrm{C} \& 2800 \mathrm{rpm}$ )

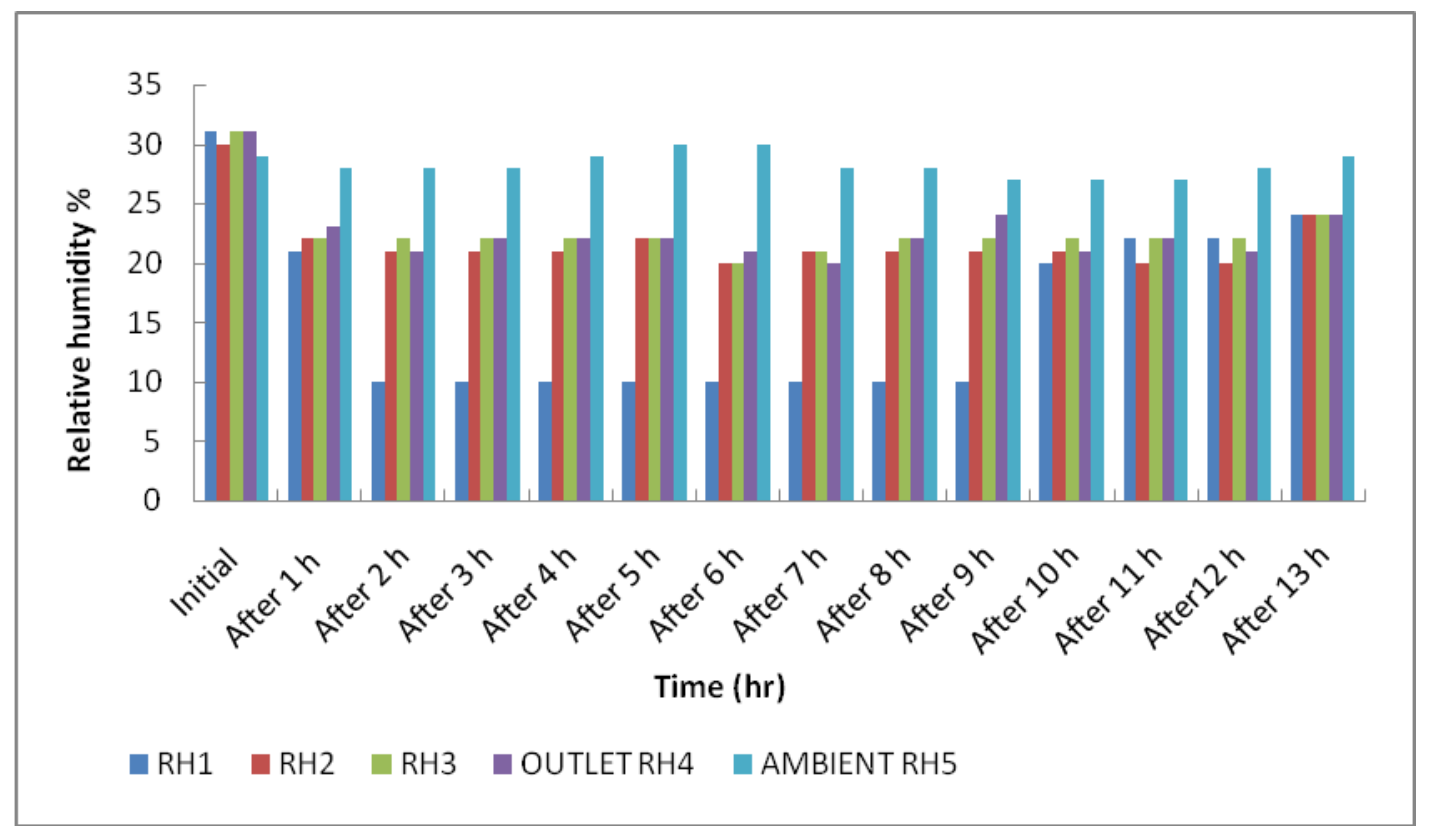

Fig.6

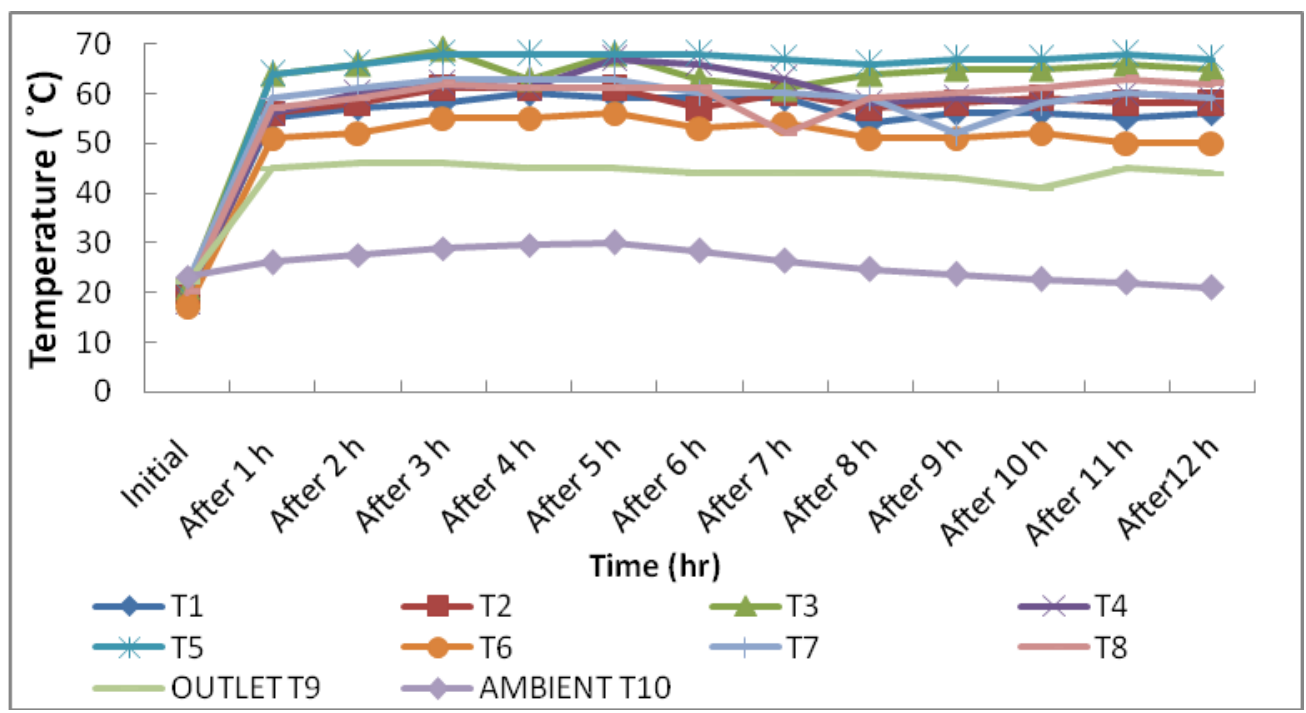

The data presented in Fig.3 showed that the temperature inside the, ambient temperature with respect to drying time. It showed that initial temperature just after starting of drier was $30^{\circ} \mathrm{C}$ corresponding to the ambient temperature $40^{\circ} \mathrm{C}$. The minimum and maximum temperatures inside the biomass based rotary tray dryer were $45^{\circ} \mathrm{C}$ and $55^{\circ} \mathrm{C}$ respectively corresponding to the constant feeding temperature of $55^{\circ} \mathrm{C}$ at $2800 \mathrm{rpm}$ respectively. The outlet temperature was $36^{\circ} \mathrm{C}$. The relative humidity inside the biomass rotary drier was found to be $25 \%$ corresponding to ambient relative humidity $20 \%$ respectively. The data presented in Fig 4 showed that the temperature inside the 
biomass based rotary tray dryer, ambient temperature and relative humidity with respect to drying time. It showed that initial temperature just after starting of drier was $40^{\circ} \mathrm{C}$ corresponding to the ambient temperature $31^{\circ} \mathrm{C}$. The minimum and maximum temperatures inside the biomass based rotary tray dryer were $53^{\circ} \mathrm{C}$ and $62{ }^{\circ} \mathrm{C}$ respectively corresponding to the constant feeding temperature of $55^{\circ} \mathrm{C}$ at $2800 \mathrm{rpm}$ respectively. The outlet temperature was $42^{\circ} \mathrm{C}$. The relative humidity inside the biomass rotary drier was found to be $20 \%$ corresponding to ambient relative humidity $29 \%$ respectively.

Biomass based rotary tray dryer - Drying time for Shatavari in this dryer require less $5.2 \%$ time as compared to solar tunnel dryer $\&$ open sun dryer, but the dryer require more electricity, manpower, operating cost is more $258 \mathrm{Rs} / \mathrm{kg}$ shatavari as compared to solar tunnel dryer.

\section{Solar tunnel dryer}

In this dryer does not require electricity, hence electricity cost reduced it require only 1 manpower as compared to biomass based rotary tray dryer, hence overall operating cost is less $195 \mathrm{Rs} / \mathrm{kg}$ Shatavari, but drying time for Shatavari is more $7.8 \%$ as compared to biomass based rotary tray dryer but it is safe for operation as well.

\section{Open sun dryer}

Open sun drying needs more $9.75 \%$ time for drying of Shatavari it does not require electricity and manpower, but there may not be any control and quality of product during drying. Shatavari color are totally different, foreign particles, dust may after on product drying. Hence, by considering above points drying of Shatavari in solar tunnel dryer is economical, safe and better.

Therefore, $1 \mathrm{~kg}$ of Shatavari for drying in biomass based rotary tray dryer require 258 $\mathrm{Rs} / \mathrm{kg}$ and in solar tunnel dryer $1 \mathrm{~kg}$ of Shatavari require $195 \mathrm{Rs} / \mathrm{kg}$.

\section{References}

1. Adzimah K. S. and S. Emmanuel. 2009. Improvement on the Design of a Cabinet Grain Dryer. Department of Mechanical Engineering, Faculty of Engineering, University of Mines and Technology, Tarkwa, Ghana, Vol.2(1): 217-228.

2. Anonymous. $2008^{\mathrm{a}}$. Notes from Bureau of Energy Efficiency: 1.

3. Anonymous. $2008^{\mathrm{b}}$. Notes from Bureau of Energy Efficiency: 4.

4. Anonymous. $2008^{\mathrm{c}}$. Notes from Bureau of Energy Efficiency: 8.

5. Anonymous. $2008^{\mathrm{d}}$. Biomass boilers and room heaters. Technology information leaflet ECA772, United Kingdom.

6. Anonymous. 2009. Testing and Development of CAET Dapoli developed Copra Dryer Using Coconut Husk as a Fuel. Unpublished Thesis: 68-70.

7. Aggraval, K. R., M. M. Sharma, A. K. Sharma 2010. Indirect solar drier with electric backup system for quality hill products. J. Natural Resources 1: 88-94.

8. Agrawal, R., A. Upadhyay and P. S. Nayak. 2013. Drying characteristics of Safed Musli (Chlorophytum borivilianum) and its effect on colour and saponin content J. Pharmacog. Phytother., Vol. 5(8):pp. 142-147.

9. Alpine, E. K. 2002. The development of acyclone type dryer for agricultural products. Ph.D. Thesis, Firat University, Elazig, Turkey.

10. Amer, B. M., M. A. Hussein, K. Gottschalk. 2009. Design and performance evaluation of a new hybrid solar dryer for banana. Energy Conversion and Management, 1-8.

11. Argyropoulos D, Muller J, Changes of essential oil content and composition 
during convective drying of lemon balm (Melissa officinalis L.) 2014; 52:118-124.

12. Arslan D, Ozcan M M. Evaluation of drying methods with respect to drying kinetics, mineral content and colour characteristics of rosemary leaves. Energy conversion and management. 2008; 49(5):1258-1264.

13. AOAC. Official Method of Analysis, Association of Official Analytical Chemists, Wishington,DC.U.S.A.2000.

14. AOAC. Official Methods of Analysis. 14 th Ed. Edited by Sidney Williums. Published by the Association of Official Analysis Chemists, Inc. Arlinton, Virginia, 22209, USA, 1984.

15. Ayyapan, S. and K. Mayilsamy, 2010. Solar tunnel drier with thermal storage for drying of copra. Proceedings of 37th National \& International Conference on Fluid Mechanics and Fluid Power.

16. Babar S. K. and P. Karve 2009. Natural Draft Gasifier Water Heater for Rural Households. Department of Applied Science, D.Y. Patil College of Engineering, Akurdi, Pune, Boiling Point, Vol.0: 37.

17. Basunia M. A. and T. Abe 2001. Design and Construction of a Simple Three Shelf Solar Rough Rice Dryer. Journal of Agricultural Mechanization in Asia. Africa and Latin America, 32(3): 54-59.

18. Bhagyashree P, Vanita B, Sneha D. Thin layer drying of long pepper (Piper longum L.) Journal of Spices and Aromatic Crops. 2013; 22(1):31-37.

19. Bello S. R. and T. A. Adegbulugb 2010. Comparative Study on Utilization of Charcoal, Sawdust and Rice Husk in Biomass Furnace Dryer. Agricultural Engineering International: the CIGR Journal of Scientific Research and Development. Manuscript 1592, Vol. 12

20. Belonio A., L. Larano, E. Ligisan and V. Ocon. 2012. An Indirect-Fired 6-Ton Capacity Grain Dryer with Biomass
Furnace. College of Engineering, Central Luzon State University, Science City of Munoz, Nueva Ecija, Philippines.

21. Bhattacharya S. C. 2001. Commercialization options for Biomass Energy Technologies in ESCAP Countries. Economic and Social Commission for Asia and the Pacific, Regional Seminar on Commercialization of Biomass Technology, Guangzhou, China.

22. Branislav R., D. Dakic, D. Djurovic and A. Eric. 2008. Development of a Boiler for Small Straw Bales Combustion. University of Belgrade, Vinca Institute of Nuclear Sciences, Serbia.

23. Chakraverty A. 1998, Post-harvest technology of cereals, pluses and oil seed. New Delhi, Oxford and IBH Pub. Co. Pvt. Ltd., PP. 33-39.

24. Cao, C. and X.B. Wang. 2002. Automatic control of grain driers. Modernizing Agric., 2:40-4.

25. Courtois, F., J. L. Nouafo and G. Trystram. 1995. Control strategies for corn mixed-flow dryers. Drying Technol., 13: 1153-65

26. Cheng W M, Raghavan G S V, Ngadi M, Wang N. Microwave power control strategies on the drying process. I: Development and evaluation of new microwave drying system. Journal of Food Engineering. 2006; 76:188-194.

27. Crank J. The Mathematics of Diffusion (2nd ed.) UK, Clear end on Press, Oxford. Developments in osmotic dehydration of fruits and vegetable-a review, 1975.

28. Daniel B. 1996. Design and Construction of Walk-in Hot Air Cabinet Dryer For The Food Industry. Food Research Institute, P.O. Box M.20, Accra, Ghana, Vol. 31-36: 107-112.

29. Dhanushkodi S., Vincent H., Sudhakar K., Wilson. 2015. Design and performance evaluation of biomass dryer for cashewnut processing. Advance in Applied Science 
Research, 6(8): 101-111.

30. Deshmukh, A. W., M. N. Varma, C. K. Yoo and K. L. Wasewar. 2014. Investigation of Solar Drying of Ginger (Zingiber officinale): Emprical Modelling, Drying Characteristics, and Quality Study. Chinese J. Engi., 1-7.

31. Doymaz I. Thin-Layer Drying of Bay Laurel Leaves (Laurus nobilis L.) Journal of Food Processing and Preservation. 2014; 38(1):449-456.

32. Doymaz I. Thin-layer drying behavior of mint leaves. Journal of Food Engineering. 2006; 74(3):370-375.
33. Dincer M M, Hussain, Sahin A Z, Yilbas B S. Development of a new moisture transfer (Bi-Re) correlation for food drying applications. International Journal of Heat and Mass Transfer. 2002; 45:1749-1755.

34. Ehiem J. C., S. V. Irtwange and S. E Obetta. 2009. Design and Development of an Industrial Fruit and Vegetable Dryer. Department of Agricultural and Environmental Engineering, University of Agriculture, Makurdi, Nigeria. Vol. $1(2): 44-53$.

\section{How to cite this article:}

Ghanbahadur, B. V., N. R. Nandagawali and Shinde, V. B. 2021. Comparative Study of Performance Evaluation of Biomass based Rotary Tray Dryer and Solar Tunnel Dryer for Drying of Shatavari Roots (Asparagus racemosus). Int.J.Curr.Microbiol.App.Sci. 10(12): 158168. doi: https://doi.org/10.20546/ijcmas.2021.1012.018 